\title{
Effects of partially replacing skimmed milk powder with dairy ingredients on rheology, sensory profiling, and microstructure of probiotic stirred-type yogurt during cold storage
}

\author{
A. P. Marafon, ${ }^{*}$ A. Sumi, ${ }^{*}$ D. Granato, ${ }^{*}$ M. R. Alcântara,$\dagger$ A. Y. Tamime,$\neq^{1}$ and M. Nogueira de Oliveira ${ }^{* 2}$ \\ *Department of Biochemical and Pharmaceutical Technology, São Paulo University, Av Prof Lineu Prestes, 580 São Paulo, Brazil \\ †São Paulo University, Chemistry Institute, Av Professor Lineu Prestes, 580 Bloco 3, 05508-900 São Paulo, Brazil \\ $\ddagger 24$ Queens Terrace, Ayr KA7 1DX, Scotland, United Kingdom
}

\begin{abstract}
This study aimed to evaluate the quality of stirredtype skim milk probiotic yogurt fortified by partially replacing skim milk powder (SMP) with whey protein concentrate (WPC) and sodium caseinate (Na-CN) during cold storage for $28 \mathrm{~d}$ compared with nonfortified yogurt. The rheological properties (as measured using dynamic oscillation) and sensory profiles of probiotic yogurts were greatly enhanced when SMP (i.e., 45\%) was replaced with WPC and Na-CN. Higher values of mechanical parameters related to storage and loss modulus and consistent microstructure were found in the fortified yogurts. The acidification profile was not affected by supplementation of the solids in the milk base, and the viable counts of probiotic microbiota were high and satisfactory. These positive characteristics of probiotic yogurts were maintained until the end of the storage period. The microstructure of the fortified yogurt showed some differences compared with the nonfortified product, which were due to changes in chemical composition of the milk base in addition to the colloidal characteristics of the product.
\end{abstract}

Key words: probiotic yogurt, fortification, sensory, microstructure

\section{INTRODUCTION}

Yogurt is a fermented product made from milk fortified with dairy ingredients, mainly skim milk powder (SMP), and by using a mixed starter culture that consists of Lactobacillus delbrueckii ssp. bulgaricus and Streptococcus thermophilus (Tamime and Robinson, 2007). Over the past few decades, the development of yogurt as a product that has health benefits for consum-

Received March 15, 2011

Accepted July 16, 2011.

${ }^{1}$ Retired from the Scottish Agricultural College; currently a dairy consultant.

${ }^{2}$ Corresponding author: monolive@usp.br ers has included the addition of probiotic microorganisms (i.e., Lactobacillus spp. and Bifidobacterium spp.) and prebiotic ingredients that stimulate the growth of these organisms in the intestinal tract (Shah, 2001; Tamime, 2006).

The manufacture of probiotic yogurt involves fortification of the milk base with dairy ingredients to increase the protein concentration to between 40 and $50 \mathrm{~g} / \mathrm{kg}$ (Sodini et al., 2005b). Afterward, the milk base is preheated to 60 to $70^{\circ} \mathrm{C}$, homogenized at 17 to 20 $\mathrm{MPa}$, heated (e.g., $95^{\circ} \mathrm{C}$ for $5 \mathrm{~min}$ ), cooled to fermentation temperature (e.g., $42^{\circ} \mathrm{C}$ ), and inoculated with starter cultures. In general, yogurts are presented to consumers in a gel-like form (set yogurt) or as a viscous fluid (stirred yogurt), and the main difference between these types of yogurt whether the gel is broken. Gel formation is one of the main properties during the manufacture of yogurt. The rheological properties of the gel are affected by the composition of the milk base, temperature and time of heat treatment, the type and amount of culture used, temperature of fermentation, whether the gel is stirred, and storage conditions until the end of shelf-life of the product (Lucey et al., 1998; $\mathrm{Xu}$ et al., 2008). The structure of fermented milks is complex, although they contain high levels of moisture (i.e., same amount as in the milk base), and the gel formed behaves as a solid-like material. This behavior is due to the aggregation of casein micelles in the milk and formation of a 3-dimensional network, with fat embedded in the matrix (Tamime et al., 2007).

Skim milk powder is widely used to fortify the solids level in the milk base before processing and fermentation. Currently, different powders such as skim milk retentate, whole milk retentate, whey protein concentrates (WPC), and instant-type caseinates are available on the market and are blended depending on the formulation of the milk base. Fortification of the protein content in the milk base improves the texture and enhances the nutritional and functional properties of the product (Séverin and Wenshui, 2005; Vasiljevic and Shah, 2008). The effects of replacing SMP with 
WPC or caseinates on the texture and physicochemical properties of yogurt have been widely studied by many researchers (Dannemberg and Kessler, 1988; Oliveira et al., 2001; Bhullar et al., 2002; Lucas et al., 2004; Tamime and Robinson, 2007; Akalin et al., 2008; Damin et al., 2008, 2009). To our knowledge, fewer studies are available to demonstrate the effect of incorporation of these powders on the structure of yogurt (Sodini et al., 2004, 2005b). Bhullar et al. (2002) reported that fortification of the milk base with WPC $(2 \mathrm{~g} / 100 \mathrm{~g})$ produced the firmest yogurt compared with the control, and that the microstructure of the product was a more regular and dense protein network compared with yogurts fortified with whey powder or SMP; however, the same yogurt contained fewer void and interstitial spaces compared with other products.

In a previous study, the optimization of the rheological properties of probiotic yogurts supplemented with milk proteins was reported by Marafon et al. (2011), who concluded that the optimal fortification of the milk base involved partial replacement of SMP with a blend of WPC and sodium caseinate (Na-CN). Hence, the current study aimed to (1) partially replace SMP with a mixture of WPC and $\mathrm{Na}-\mathrm{CN}$ in the milk base to enhance the rheological properties and modify the microstructure of probiotic yogurt; and (2) characterize the rheological properties of the products, taking into account the kinetics of acidification, sensory profiling of the product, and enumeration of viable bacteria in the yogurts during $28 \mathrm{~d}$ of storage.

\section{MATERIALS AND METHODS}

\section{Experimental Procedure}

Three ingredients were used to increase the protein content of the milk bases by $1 \mathrm{~g} / 100 \mathrm{~g}$ in the probiotic yogurts: (1) SMP (Cooperativa Taquarense de Laticínios Ltda, Taquara, Brazil); (2) WPC (Lacprodan-35, Aria Food Ingredients, Viby, Germany), and (3) Na-CN (EM 7, DMV International, Veghel, the Netherlands). The WPC, Na-CN, and SMP contained 36.6, 86.5, and $32.3 \mathrm{~g}$ of protein $/ 100 \mathrm{~g}$, respectively, as determined by micro-Kjeldahl analysis (AOAC, 1995).

Three strains of pure commercial starter cultures for direct-to-vat inoculation were used to ferment the milk bases: (1) Streptococcus thermophilus, (2) Lactobacillus delbrueckii ssp. bulgaricus (Delvo-Yog, CY-340 DSL, DSM, Heerlen, the Netherlands), and (3) the probiotic culture Bifidobacterium animalis ssp. lactis (B94 LAFTI, DSM).

The milk base for nonfortified yogurt was prepared by adding $12 \mathrm{~g}$ of SMP to $88 \mathrm{~g}$ of potable water at $25^{\circ} \mathrm{C}$. To prepare the fortified yogurt, the milk base prepared as for the nonfortified product was supplemented with a mixture of $0.52 \mathrm{~g}$ of WPC/100 g of milk base, $0.42 \mathrm{~g}$ of Na-CN/100 g of milk base, and $1.39 \mathrm{~g}$ of SMP/100 g of milk base, which corresponded to partially replacing SMP by $45 \mathrm{~g} / 100 \mathrm{~g}$, which was previously indicated to be the optimum milk base composition to produce excellent viscoelastic properties of probiotic yogurt (Marafon et al., 2011). In addition, the same formulation corresponded to an increase of the protein content $(\mathrm{g} / 100 \mathrm{~g})$ of $0.19,0.36$, and 0.45 when using WPC, Na$\mathrm{CN}$, and SMP, respectively, or an increase equivalent to $1 \mathrm{~g}$ of protein/100 $\mathrm{g}$ of content in the milk base.

After reconstitution and supplementation of the milk bases, each batch of milk was preheated to $55^{\circ} \mathrm{C}$ in an Alfa Laval plate heat exchanger Type A3-HRB (AlfaLaval, Lund, Sweden), homogenized at 10 and $5 \mathrm{MPa}$ in double-stage homogenizer (Treu, Rio de Janeiro, Brazil), heated at $95^{\circ} \mathrm{C}$ for $5 \mathrm{~min}$ in closed circuit, and cooled to $10^{\circ} \mathrm{C}$ in the same plate heat exchanger.

Two inocula were prepared separately: (1) Strep. thermophilus and L. delbrueckii ssp. bulgaricus, the "classical" yogurt starter culture (10 g of Delvo-Yog CY-340 DSL), was weighed and rehydrated in 150 $\mathrm{mL}$ of sterilized milk $\left(121^{\circ} \mathrm{C}\right.$ for $\left.10 \mathrm{~min}\right)$, and (2) B. animalis ssp. lactis or probiotic starter culture (10 g of B94 LAFTI) was weighed and rehydrated in $500 \mathrm{~mL}$ of sterilized milk $\left(121^{\circ} \mathrm{C}\right.$ for $\left.10 \mathrm{~min}\right)$. Each batch of sterilized milk was tempered to $42^{\circ} \mathrm{C}$ for 15 min before inoculation.

Starter culture (a blend of $0.2 \mathrm{~mL}$ of yogurt and 2.5 $\mathrm{mL}$ of probiotic ) was added to $250 \mathrm{~mL}$ of milk base and incubated at $42^{\circ} \mathrm{C}$ in a thermostatically controlled water bath until the $\mathrm{pH}$ reached 4.5, when the fermentation time was noted. The rate of acidification of each trial was monitored by using the Cinac system (Ysebaert, Frépillon, France). After reaching pH 4.5, each fermentate was agitated manually using a stainless steel plunger (consisting of a rod and perforated disc) that was moved up and down for $60 \mathrm{~s}$; then, each fermentate was dispensed into $50-\mathrm{mL}$ polypropylene cups (heat sealed using Selopar equipment, BrasHolanda, Pinhais, Brazil), quickly cooled in an ice bath, and stored at $4^{\circ} \mathrm{C}$ until required for analysis. From the data obtained, the acidification rate $(\mathbf{d p H} / \mathbf{d t}$; milliunits $\mathrm{pH} / \mathrm{min})$, was calculated by using Cinac software (version 4, release 0.2.f; AMS, Frépillon, France). At the end of the fermentation period, the following kinetic parameters were also calculated: (1) maximum acidification rate $\left(\mathbf{V}_{\max }\right)$; (2) time in which the maximum acidification rate was reached $\left(\mathbf{t}_{\mathbf{V} \text { max }} ; \mathrm{h}\right) ;(3) \mathrm{pH}$ at maximum acidification rate $\left(\mathbf{p H}_{\mathbf{V m a x}}\right)$; and (4) time to reach $\mathrm{pH} 5.5$ and 4.5 $\left(\mathbf{t}_{\mathrm{pH} 5.5}\right.$ and $\mathbf{t}_{\mathrm{pH} 4.5}$, respectively). The samples were prepared in duplicate and the experiment was replicated twice on different days. 


\section{Physico-Chemical Determinations}

The protein, total solids, and fat contents of the milk bases were determined using an ultrasonic milk analyzer (Ekomilk, Eon Trading, Stara Zagora, Bulgaria), and replicated 10 times (Venturoso et al., 2007).

The $\mathrm{pH}$ of the yogurts (nonfortified and fortified) were determined using a $\mathrm{pH}$ meter (model Q-400M1, Quimis, Diadema, Brazil). Analyses were performed in duplicate after $1,7,14,21$, and $28 \mathrm{~d}$ of product storage at $4^{\circ} \mathrm{C}$.

\section{Bacterial Counts of Yogurt and Probiotic Cultures}

Enumeration of yogurt and probiotic microorganisms was made on d 1, 7, 14, 21, and 28 after fermentation in 4 replicates. Each sample $(1.0 \mathrm{~mL})$ was added to $9.0 \mathrm{~mL}$ of $0.1 \%(\mathrm{~g} / 100 \mathrm{~mL})$ sterile peptonized water and appropriate dilutions were made. Subsequently, Strep. thermophilus and L. delbrueckii ssp. bulgaricus were enumerated in M17 agar and de Man, Rogosa, and Sharpe (MRS) agar, respectively (Oxoid Ltd., Basingstoke, UK); the latter agar was previously acidified to pH 5.4 with acetic acid, and the plates were incubated at $37^{\circ} \mathrm{C}$ for $48 \mathrm{~h}$ (Saccaro et al., 2009). Bifidobacterium animalis ssp. lactis was enumerated in reinforced clostridia agar agar plus $1 \mu \mathrm{L} / \mathrm{mL}$ of dicloxacillin $(\mathrm{pH}$ 7.1 ) and $0.3 \mathrm{~g} / 100 \mathrm{~g}$ of aniline, and incubated under anaerobic conditions at $37^{\circ} \mathrm{C}$ for $72 \mathrm{~h}$. Anaerobic conditions were ensured by the use of AnaeroGen (Oxoid Ltd.). The enumeration of the microbial counts was performed on plates containing 30 to 300 colonies, and the counts were expressed as $\log _{10} \mathrm{cfu} / \mathrm{mL}$ of yogurt.

\section{Rheological Measurements}

The yogurts packed in cups, stored at $4^{\circ} \mathrm{C}$ during 28 $\mathrm{d}$, were gently stirred 5 times in a clockwise direction before rheological analysis. The viscoelastic properties were determined by small amplitude oscillatory measurement using a controlled stress rate rheometer (Physica MCR 300, Anton Paar GmbH, Ostfildern, Germany) equipped with cone-plate geometry (CP25-1, $12.5 \mathrm{~mm}$ diameter, $1^{\circ}$ angle, and 0.05-mm gap, Anton Paar $\mathrm{GmbH}$ ). The temperature of the system was controlled at $26 \pm 1^{\circ} \mathrm{C}$ by a viscotherm VT2 circulating bath and a Peltier system (Anton Paar GmbH).

Approximately $0.1 \mathrm{~mL}$ of yogurt sample was loaded on the inset plate and the sample was allowed to equilibrate to $26^{\circ} \mathrm{C}$ for $5 \mathrm{~min}$ before small amplitude oscillatory measurement was performed. Subsequently, the samples were subjected to a shear stress sweep test (shear stress increased from 1.0 to $50 \mathrm{~Pa}$ ) at a constant frequency of $1 \mathrm{~Hz}$ to ascertain the storage modulus
$\left(\mathbf{G}^{\prime}\right)$, loss modulus $\left(\mathbf{G}^{\prime \prime}\right)$, damping factor $(\tan \boldsymbol{\delta})$, and gamma (the amount of stress that determines the susceptibility of protein network breakage). For all tests, 6 replicates were performed and a fresh sample was used for each replicate at d 1, 7, 14, 21 and 28 of storage at $4^{\circ} \mathrm{C}$.

\section{Sensory Profile}

Sensory profiling was carried out to assess appearance, acidic taste, and consistency at 1 and $28 \mathrm{~d}$ of storage of the products at $4^{\circ} \mathrm{C}$. Analyses were performed by 120 untrained panelists. About $50 \mathrm{~mL}$ of each sample was served in a white plastic cup, randomly coded with a 3-digit number. Analysis sessions were always conducted $2 \mathrm{~h}$ before meals, which is the time most adapted for accomplishment of these evaluations (Dethemers, 1981; Moraes, 1985; Muños et al., 1992); 2 samples were served in each session. A structured 9-point scale was used to evaluate the sensory properties of yogurt as follows: $9=$ very good (i.e., good appearance, not very acidic, characteristic taste, and good or firm consistency), and $1=$ bad (i.e., very acid, bitter, off-flavor, and weak consistency or fluid) (Stone and Sidel, 1993; Grappin and Beuvier, 1997).

All yogurt samples destined for sensory evaluation were subjected to microbiological examination for yeasts and molds using Yeast and Mold Petrifilm (3M Petrifilm, St. Paul, MN) incubated at $21^{\circ} \mathrm{C}$, and for Escherichia coli and total coliforms using Coliform Petrifilm $\left(3 \mathrm{M}\right.$ Petrifilm) incubated at $37^{\circ} \mathrm{C}$. After analyzing the results and confirming that these microorganisms were not detected in the product, the samples were approved for consumption and used in sensory evaluations.

The project received approval from the Ethics Committee in Research of the Faculty of Pharmaceutical Sciences, São Paulo University (process number P-449).

\section{Microstructure}

Yogurt samples (nonfortified and fortified) stored at $4^{\circ} \mathrm{C}$ for $1 \mathrm{~d}$ and $28 \mathrm{~d}$ were freeze-dried using an Edwards freeze dryer (model L4KR 118, BOC Edwards, São Paulo, Brazil). The dried samples were placed on stubs covered with double-sided tape, and a final goldpalladium coating about $15 \mathrm{~nm}$ thick was applied by cathodic spreading of the samples in a Polaron E 5100 coater (Polaron, West Sussex, UK). The gold-coated samples were placed for observation in a field-emission scanning electron microscope (model JSM-7401-F, Jeol Ltd., Tokyo, Japan), operating at a voltage of 1.0 to $10.0 \mathrm{kV}$. The images were registered under magnifications from 5,000 to $10,000 \times$, and 6 fields were observed. Images (JPEG files) were analyzed using the software 
Table 1. Chemical composition of the traditional and experimental milk bases

\begin{tabular}{|c|c|c|c|c|c|c|c|}
\hline $\begin{array}{l}\text { Milk } \\
\text { base }\end{array}$ & \multicolumn{3}{|c|}{ Ingredients $^{1}(\mathrm{~g} / 100 \mathrm{~g})$} & \multicolumn{4}{|c|}{ Chemical composition } \\
\hline Experimental & 0.52 & 0.42 & 1.39 & $4.72 \pm 0.01^{\mathrm{b}}$ & $12.50 \pm 0.02^{\mathrm{b}}$ & $4.50 \pm 0.01^{\mathrm{a}}$ & $0.38 \pm 0.02^{\mathrm{a}}$ \\
\hline
\end{tabular}

Image Pro Plus v.4.5.1 (Media Cybernetics, Bethesda, MD).

\section{Statistical Analysis}

General linear model and ANOVA for multiple comparisons were performed to confirm the statistical significance of differences among samples. Mean values were compared using the Tukey test at $P \leq 0.05$. A multivariate approach using principal component analysis (PCA) was carried out to study and the differences in sensory attributes among the yogurt samples during the cold storage period. For this purpose, the sensory attributes were adopted as columns and the samples (each day for each treatment was considered the same) as rows. Factor loadings $>0.55$ were used to project the variable in the factor plane (Granato et al., 2010). All the statistical procedures were performed using the software package Statistica v. 9.0 (Statsoft, Tulsa, OK).

\section{RESULTS}

\section{Physico-Chemical Determinations and Acidification Profile}

The chemical composition (protein, total solids, and $\mathrm{pH}$ ) of the nonfortified and fortified milk bases were analyzed before fermentation; the data are shown in Table 1. The protein content of milk supplemented with SMP, WPC, and Na-CN (4.72 g/100 g of protein) was higher than that of the nonfortified milk base by approximately $1 \mathrm{~g}$, as expected. Although the total solids content of the fortified milk base was significantly higher that of the nonfortified milk base $(P \leq 0.05)$, the relative amount of the total solids:protein was slightly different but the $\mathrm{pH}$ levels were similar. Figure 1 shows the acidification curve of nonfortified and fortified yogurts. The decrease in $\mathrm{pH}$ during the fermentation period was similar in both types of yogurt, and the supplementation of the milk base with milk proteins did not extend production time. Thus, such fortification could be applied on an industrial scale without affecting productivity, because no increase in fermentation time was noted.
The results of the kinetic parameters of acidification $\left(\mathrm{t}_{\mathrm{pH} 5.5}, \mathrm{t}_{\mathrm{pH} 4.5}, \mathrm{~V}_{\max }, \mathrm{t}_{\mathrm{Vmax}}\right.$, and $\left.\mathrm{pH}_{\mathrm{Vmax}}\right)$ of the nonfortified and fortified yogurts are shown in Table 2. Many factors such as growth characteristics, specific growth rate, fermentation time, sugar or amino acids consumption, and product yields are significantly influenced by $\mathrm{pH}$ (Rault et al., 2009). The kinetic parameters $\mathrm{pH}_{\mathrm{Vmax}}$ and $\mathrm{V}_{\max }$ are relatively constant for a given strain (Picque et al., 1992), and are useful to verify and validate the measures obtained by the Cinac system. In contrast, $t_{\mathrm{V} \max }$ and $\mathrm{t}_{\mathrm{pH}}$ are temporal descriptors that depend on cell concentration (Wang et al., 2005), and the physiological state of bacteria and operating conditions (Béal and Corrieu, 1994). Thus, the higher the value of $t_{\mathrm{pH} 5.5}$, the lower the acidification activity of the starter organisms. In the current study, the milk base supplemented with WPC, Na-CN, and SMP did not significantly affect kinetic parameters $(P \leq 0.05)$. Nevertheless, studies by different researchers (Oliveira et al., 2001; Martinéz et al., 2003; Sodini et al., 2005b) report that the enrichment of milk with milk proteins might influence kinetic parameters.

\section{Enumeration of Viable Bacterial Counts and Evolution of $\mathrm{pH}$}

The cell counts of starter culture (Strep. thermophilus and L. delbrueckii ssp. bulgaricus) and the probiotic bacteria (B. animalis ssp. lactis) in the inoculum were $8.47 \pm 0.09,7.71 \pm 0.01$, and $9.22 \pm 0.10 \log _{10} \mathrm{cfu} /$ $\mathrm{mL}$, respectively. Moreover, the counts of viable cells in probiotic yogurts (nonfortified and fortified) during cold storage at $4^{\circ} \mathrm{C}$ are shown in Table 3 .

The counts of Strep. thermophilus in the nonfortified and probiotic yogurts ranged between 9.31 and 9.78 $\log _{10} \mathrm{cfu} / \mathrm{mL}$ during the storage period (i.e., a reduction of approximately $3.5 \%$ by d 28); this reduction was not significant (Table 3). In contrast, the counts of L. delbrueckii ssp. bulgaricus during cold storage of yogurts ranged between 5.17 and $5.73 \log _{10} \mathrm{cfu} / \mathrm{mL}$, and enumeration of lactobacilli was only possible until d 14 (Table 3). It is evident that the low counts of $L$. delbrueckii ssp. bulgaricus in the starter culture 

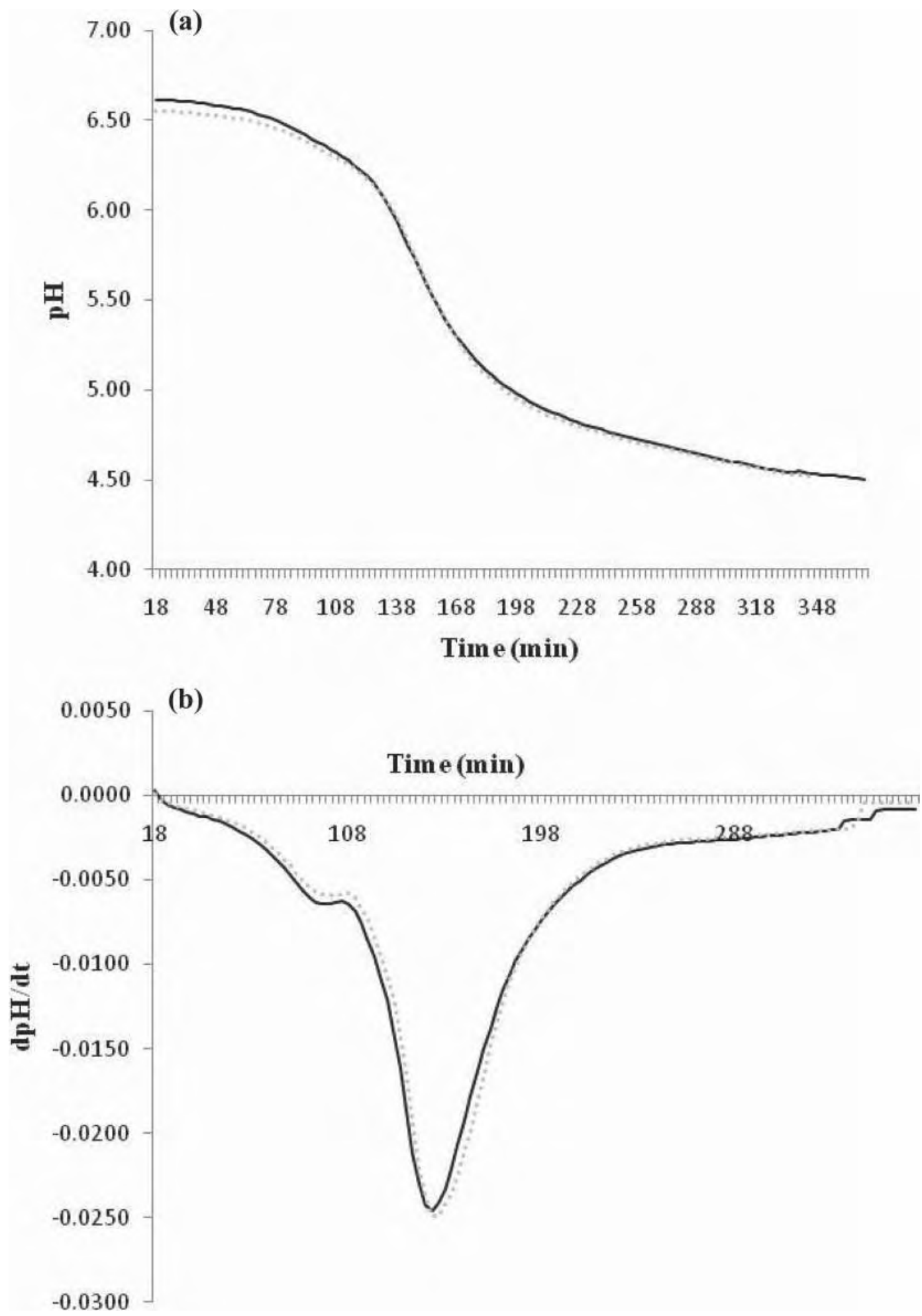

Figure 1. Acidification profile of nonfortified (solid curve) and fortified (dotted curve) yogurts: (a) evolution of $\mathrm{pH}$ with fermentation time; (b) evolution of acidification rate $(\mathrm{dpH} / \mathrm{dt})$ with fermentation time. Curves are average of 4 replicates. 
Table 2. Kinetic acidification parameters of the traditional and experimental milk bases fermented at $42^{\circ} \mathrm{C}$ until $\mathrm{pH} 4.5$

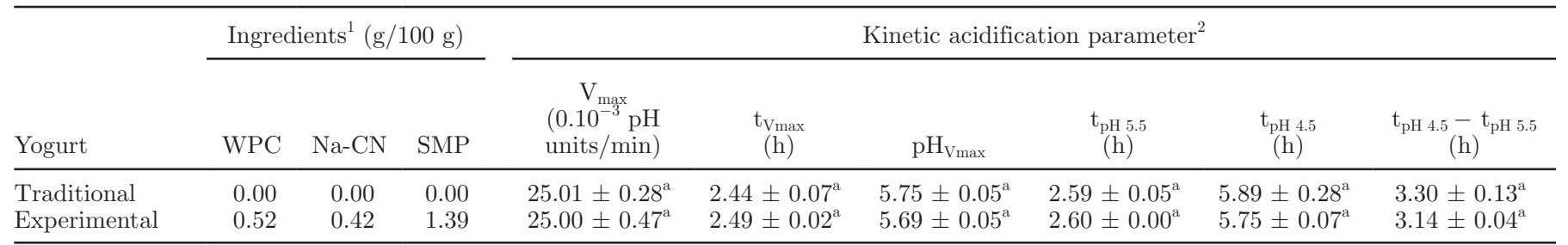

${ }^{\mathrm{a}}$ Means $(\mathrm{n}=4) \pm \mathrm{SD}$ with different letters in the same column are significantly different $(P \leq 0.05)$.

${ }^{1} \mathrm{WPC}=$ whey protein concentrate; $\mathrm{Na}-\mathrm{CN}=$ sodium caseinate; $\mathrm{SMP}=$ skim milk powder.

${ }^{2} \mathrm{~V}_{\max }=$ maximum acidification rate; $\mathrm{t}_{\mathrm{V} \max }=$ time to reach the maximum acidification rate; $\mathrm{pH}_{\mathrm{V} \max }=\mathrm{pH}$ corresponding to $\mathrm{V}_{\max } ; \mathrm{t}_{\mathrm{pH}} 5.5$ and $\mathrm{t}_{\mathrm{pH} 4.5}=$ time in hours to reach $\mathrm{pH} 5.5$ and 4.5 , respectively.

(i.e., original inoculum was $7.71 \pm 0.01 \log _{10} \mathrm{cfu} / \mathrm{mL}$ ) is intended by the supplier of the commercial starter culture company to avoid post-fermentation acidification in probiotic yogurts during storage.

Differences in the counts of $B$. animalis ssp. lactis were evident in the nonfortified and fortified probiotic yogurts (Table 3 ). In the nonfortified product, the counts ranged between $6.63 \log _{10} \mathrm{cfu} / \mathrm{mL}(\mathrm{d} 1)$ and $6.78 \log _{10} \mathrm{cfu} / \mathrm{mL}(\mathrm{d} 28)$ and averaged $6.77 \log _{10} \mathrm{cfu} /$ $\mathrm{mL}$, and no significant differences were observed in the counts of bifidobacteria during the cold storage of the nonfortified probiotic yogurt. However, in the fortified probiotic yogurts, the counts of $B$. animalis ssp. lactis averaged $7.07 \log _{10} \mathrm{cfu} / \mathrm{mL}$; that is, an increase of approximately $4.5 \%$ compared with the nonfortified product, and a slight decrease in the counts $(6 \%)$ was observed between d 1 and 28 of the storage period. It has been shown that Bifidobacterium is susceptible to aerobic conditions of storage (Dave and Shah, 1997).

The counts of viable bifidobacteria in this study were within the recommended range $\left(6-8 \log _{10} \mathrm{cfu} / \mathrm{mL}\right)$ as reported by Vasiljevic and Shah (2008). However, Florence et al. (2009) reported that different strains of $B$. animalis ssp. lactis (BB12, BL04, B94, and HN019) in coculture with Strep. thermophilus (TA040) had higher viable counts of bifidobacteria in organic and conventional fermented milks after $24 \mathrm{~h}$ of fermentation.
The changes in the $\mathrm{pH}$ values of the nonfortified and fortified probiotic yogurts during $4 \mathrm{wk}$ of storage did not show any significant differences, and ranged between 4.51 (d 1) and 4.24 (d 28) (Figure 2). In contrast, Almeida et al. (2009) studied the acidification rates of L. delbrueckii ssp. bulgaricus, Lactobacillus acidophilus, Lactobacillus rhamnosus, and B. animalis ssp. lactis in coculture with Strep. thermophilus in Minas Frescal cheese whey, and reported that all the fermented products showed development of acidity during 24 $\mathrm{h}$ of storage, and lowest values when using a Strep. thermophilus-B. animalis ssp. lactis coculture.

\section{Rheological Properties}

The analysis of G' with shear stress ranged between 0.97 and 5.21 $\mathrm{Pa}$, with very different behaviors noted between the nonfortified and fortified yogurts (data not shown). In the nonfortified product, shear stress decreased during the first part of the storage period, remained constant between $\mathrm{d} 7$ and 14, and reached the lowest value on the last day of the storage period. The fortified yogurt showed an increase in shear stress between $\mathrm{d} 1$ and 14 and a slight decrease between $\mathrm{d}$ 14 and 21, and it then remained constant until d 28. For G" in the same range of the shear stress, the same behavior was observed for G" in both the nonfortified

Table 3. Enumeration of the starter culture organisms during the storage period at $4^{\circ} \mathrm{C}$

\begin{tabular}{|c|c|c|c|c|c|c|}
\hline $\begin{array}{l}\text { Storage } \\
\text { time (d) }\end{array}$ & \multicolumn{6}{|c|}{ Counts of viable bacteria ${ }^{1}\left(\log _{10} \mathrm{cfu} / \mathrm{mL}\right)$} \\
\hline 1 & $9.70 \pm 0.02$ & $5.47 \pm 0.00$ & $6.63 \pm 0.00$ & $9.78 \pm 0.03$ & $5.73 \pm 0.00$ & $7.31 \pm 0.00$ \\
\hline 21 & $9.31 \pm 0.04$ & $5.17 \pm 0.12$ & $6.96 \pm 0.12$ & $9.64 \pm 0.05$ & $<5.0$ & $6.89 \pm 0.09$ \\
\hline 28 & $9.33 \pm 0.05$ & $<5.0$ & $6.78 \pm 0.00$ & $9.43 \pm 0.02$ & $<5.0$ & $6.88 \pm 0.36$ \\
\hline
\end{tabular}

${ }^{1}$ Means $(\mathrm{n}=4) \pm \mathrm{SD}$.

${ }^{2}$ Fortified with whey protein concentrate $(0.52 \mathrm{~g} / 100 \mathrm{~g})$, sodium caseinate $(0.42 \mathrm{~g} / 100 \mathrm{~g})$, and skim milk powder $(1.39 \mathrm{~g} / 100 \mathrm{~g})$. 


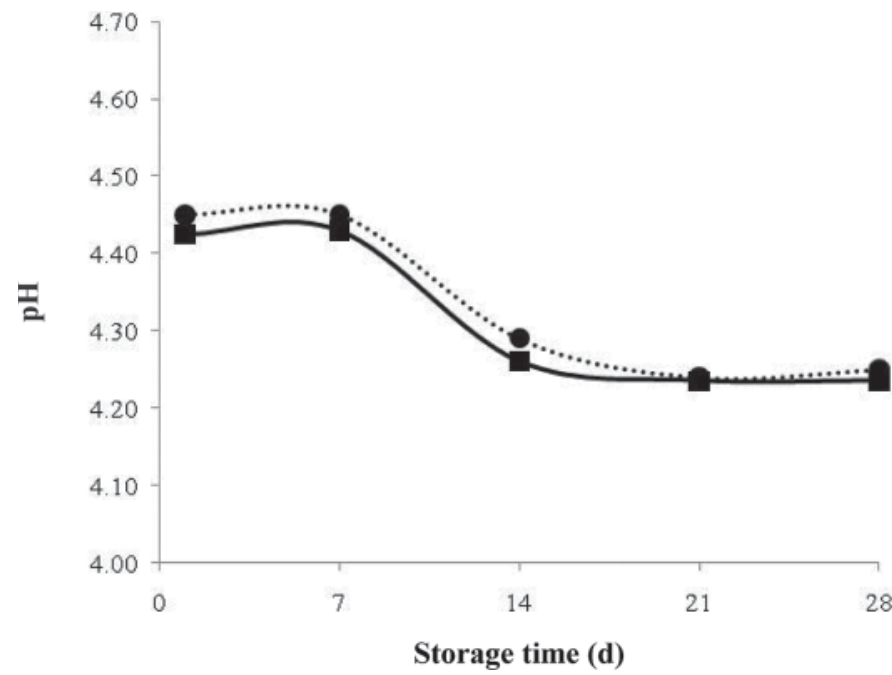

Figure 2. Evolution of $\mathrm{pH}$ during cold storage of nonfortified (----) and fortified (-口-) yogurts.

and fortified yogurts (data not shown). The nonfortified yogurt showed a steady decrease of G' value $(79.7$ to $16.2 \mathrm{~Pa}$ ) during the storage period, a reduction of $80 \%$ compared with that on $\mathrm{d} 1$. In contrast, the fortified yogurt showed a significant increase of the G' value until d 14 (approximately 60\%), followed by a slight decline from d 21, which remained almost constant until d 28. In contrast, G" values were much lower than G' values during storage (Figure $3 \mathrm{~b}$ ). The G' values of the nonfortified yogurt ranged between 31.6 and 9.6 $\mathrm{Pa}$, a decrease of up to $70 \%$ during the storage period, whereas the G" values in the fortified yogurt varied between 55 and $72.4 \mathrm{~Pa}$, with a significant increase $(\sim 30 \%)$ until d 14 (i.e., maximum G" value), followed by a small decline by $\mathrm{d} 28$. However, the G" value was $25 \%$ higher at end of the storage period than that at d 1.

The relationship between G" and G' (i.e., $\tan \delta$ ) indicates the viscoelastic characteristics of the material tested (Figure 3a). According to Lucey (2001), the increase of $\tan \delta$ in acid gels made from heated milk indicated the greater possibility of rearrangement of the protein structure(s) during storage. In the nonfortified yogurt, the values of G' decreased during storage, which explains the increase in $\tan \delta$ of nonfortified yogurt during the period of analysis, reaching a peak on $\mathrm{d}$ 28 , the same time when the sample showed the lowest values of G' (data not shown). For the fortified yogurt, the slight decrease of tan $\delta$ only on d 14 of the storage period can be explained by the steady increase of $G$ ' during the same period (Figure 3a).

The amount of stress that determines the susceptibility of protein network breakage is defined by gamma values (\%); a reduction in this tension can often be related to a combination of factors, such as the rearrangement of protein particles and the formation of new protein bonds between them (Lucey, 2001). The fortified yogurt had lower gamma values than the nonfortified yogurt, showing a reduction of almost $35 \%$ by the $\mathrm{d} 28$, which may indicate a better rearrangement of the protein particles during storage (Figure $3 \mathrm{~b}$ ). In the nonfortified yogurt, a significant increase of gamma values (i.e., up to 5 times more than the fortified yogurt during the same period) occurred, which may indicate a more fragile structure of the product during storage.

\section{Sensory Evaluation}

Different types of bacteria provide different physicochemical, rheological, and sensory features in yogurts. The degree of liking of acidic taste, overall appearance, and consistency (related to creaminess) of the formulations were conducted by sensory analysis with an un-
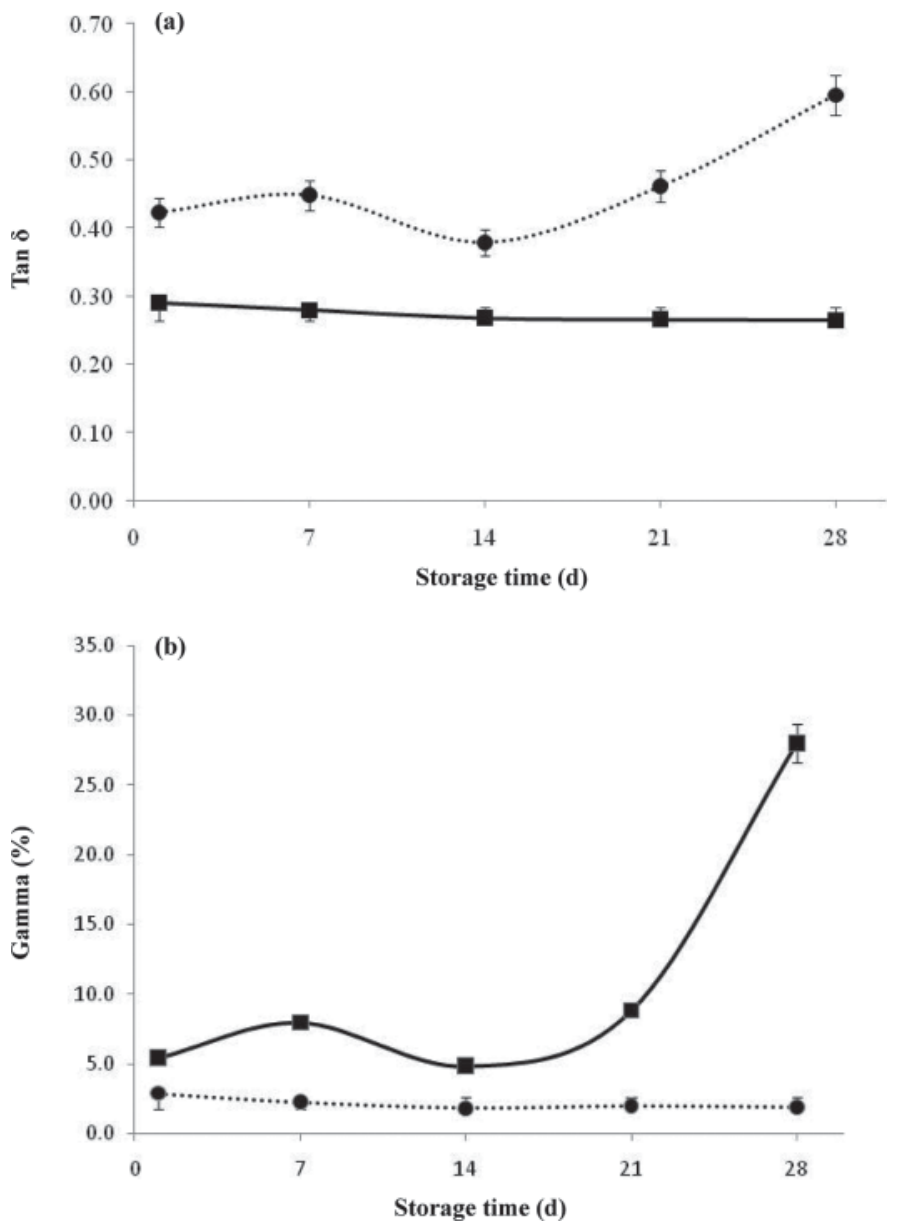

Figure 3. Effect of partially replacing skim milk powder (SMP) with whey powder concentrate (WPC) and sodium caseinate (Na-CN) on rheological properties of the fortified yogurt (- -$)$ compared with the nonfortified (----) product during cold storage: (a) $\tan \delta$; (b) gamma. Points are average of 12 replicates. 


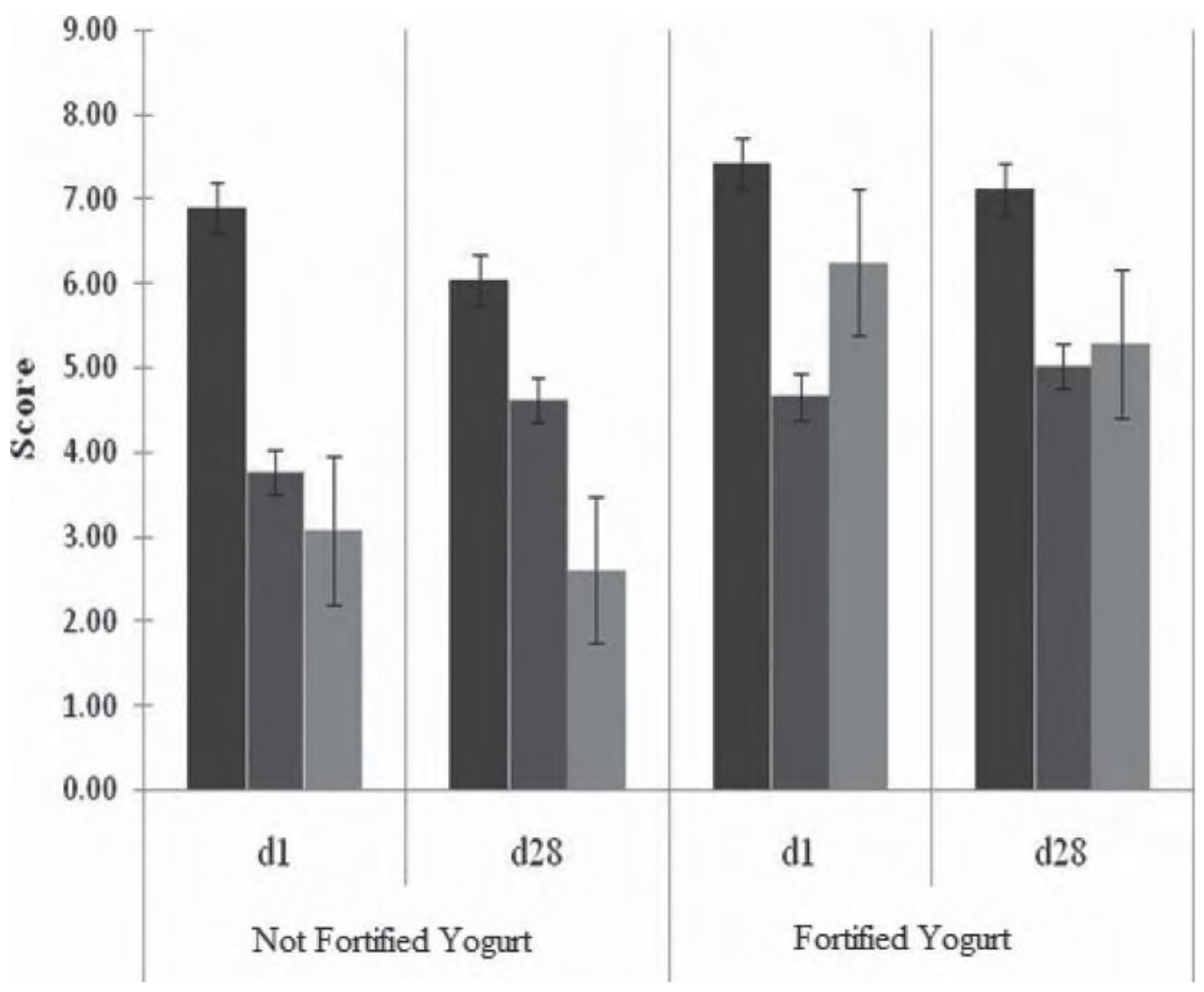

Figure 4. Summary of sensory scores of yogurts (nonfortified and fortified) during cold storage (d 1 and 28). Black bar = appearance; dark gray bar $=$ acidic taste; light gray bar $=$ consistency.

trained panel. This consumer test is well established in food companies and gives suitable results to take into consideration when optimizing the formulation of the milk base during the development of a fermented milk product (Cruz et al., 2010). A summary of the ratings for sensory attributes (appearance, acidic taste, and consistency) of yogurts (nonfortified and fortified) of 120 consumers on $\mathrm{d} 1$ and 28 is shown in Figure 4. The scores of all attributes decreased after $28 \mathrm{~d}$ of storage for both samples, and the results suggest the following: (1) the nonfortified yogurt received $12 \%$ lower score for appearance on d 28 compared with $\mathrm{d} 1$, but the fortified yogurts showed a decline of only $5 \%$ during storage; (2) the nonfortified yogurt had a significantly higher acidic taste $(21 \%)$ compared with the supplemented yogurt (6\%); and (3) similar results were noted for consistency, with declines of 16 and $14 \%$ across storage for this attribute in nonfortified and fortified yogurts, respectively.

With respect to the sensory scores of the nonfortified and fortified yogurts, the scores of all attributes of the fortified yogurts were higher. Acidic taste, which is a typical attribute in fermented milks, was consistently scored by the assessors, and the taste persisted longer in the mouth, which eventually enhanced the mouthfeel. Large differences were observed in consistency scores between samples: the fortified yogurt received scores 2 times higher than the nonfortified yogurt at $\mathrm{d} 1$ and 28 (Figure 4). These results confirm that supplementation of the milk base with milk proteins increases the consistency of the product, a fact that is well perceived by consumers; Remeuf et al. (2003), Sodini et al. (2005b), and Isleten and Karagul-Yuceer (2006) reported similar findings.

Using the multivariate analysis of the sensory ratings, we observed differences among samples according to overall sensory character. A simultaneous comparison among samples using all variables would not be possible using a univariate approach such as ANOVA; thus, samples were separated in the first principal component $(\mathbf{P C}$; eigenvalue $=2.07)$ based on differences in consistency, acidic taste, and appearance. This PC explained up to $69.1 \%$ of the variance, whereas the second $\mathrm{PC}$ (eigenvalue $=0.91$ ) was strongly correlated to acidic taste, explaining $30.2 \%$ of variability in the data (Table 4). 


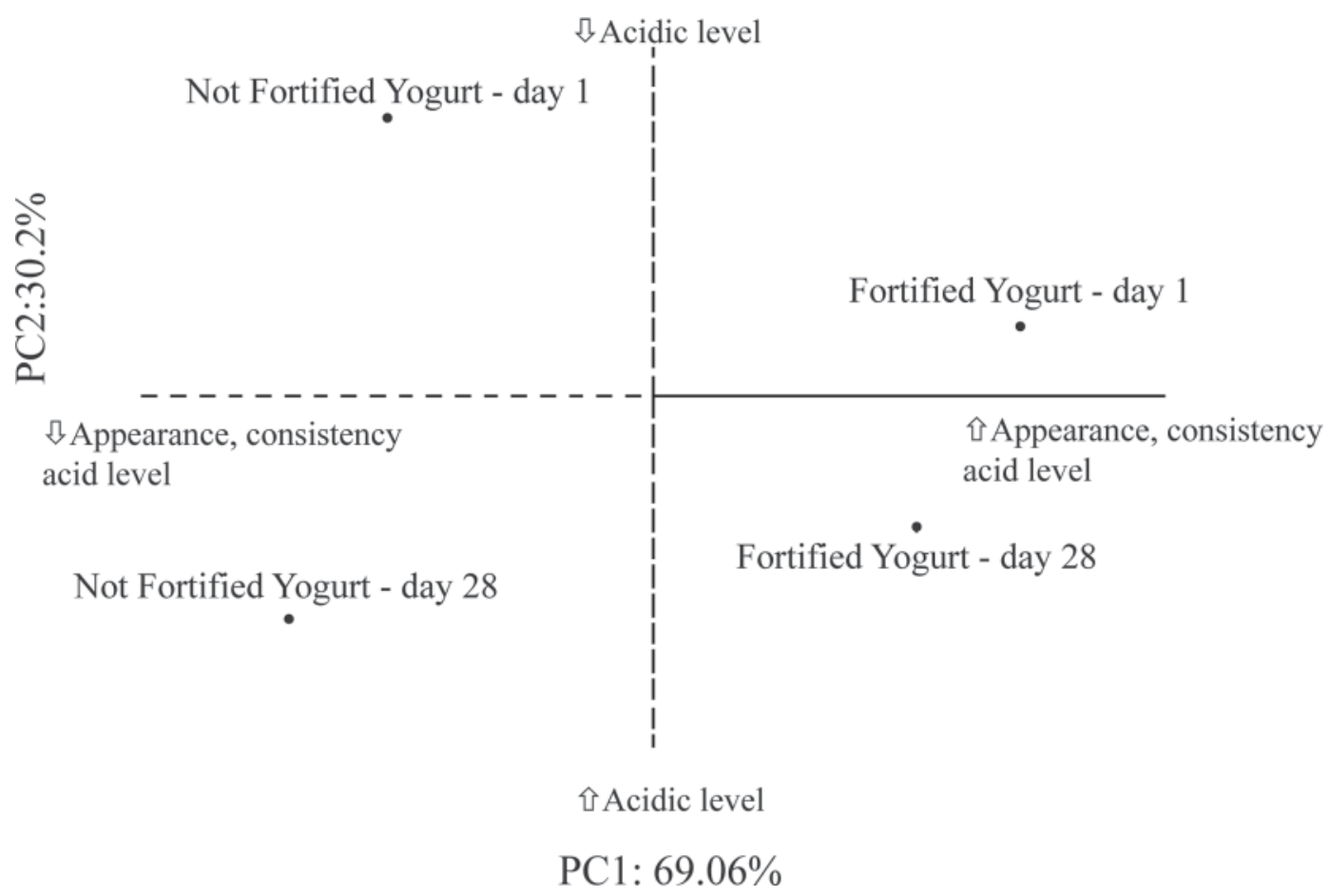

Figure 5. Principal component analysis (PCA) showing principal components (PC) 1 and 2 for the main variations of the sensory scores of nonfortified and fortified yogurts during cold storage at $\mathrm{d} 1$ and $\mathrm{d} 28$.

Although Figure 5 illustrates that both yogurts (nonfortified and fortified) tested at $\mathrm{d} 1$ and 28 garnered high scores for the sensory attributes, the nonfortified yogurts had the lower scores. This result reinforces the previous observation (Figure 4) that the fortified yogurt had better sensory characteristics than the nonfortified product.

\section{Microstructure}

Scanning electron microscopy of the yogurts at $d 1$ and 28 is shown in Figure 6, and the micrographs illustrate the differences in the microstructure of the products (i.e., compactness of the protein particles and pore sizes). The yogurts had different pore sizes that varied during the storage period. Compared with those in the

Table 4. Correlation between the original variables and the first 3 principal components ${ }^{1}$

\begin{tabular}{lcc}
\hline $\begin{array}{l}\text { Response } \\
\text { variable }\end{array}$ & Factor 1 & Factor 2 \\
\hline Appearance & 0.858 & 0.506 \\
Acidic taste & 0.591 & -0.805 \\
Consistency & 0.993 & 0.042 \\
Eigenvalue & 2.07 & 0.91 \\
Explained variance (\%) & 69.05 & 30.21 \\
\hline
\end{tabular}

${ }^{1}$ Factor 1 and factor 2 represent principal components 1 and 2, respectively. fortified yogurt, the pore sizes in the nonfortified yogurt at $\mathrm{d} 1$ were larger and more evenly distributed in the protein matrix (Figure 6, panels a and c, respectively), but the pore size of both yogurts became similar at the end of the storage period (Figure 6, panels b and $\mathrm{d}$ ). The diameter of the pore size of nonfortified and fortified yogurts varied between 0.579 and $0.534 \mu \mathrm{m}$ at $\mathrm{d} 1$, and between 0.405 and $0.443 \mu \mathrm{m}$ at $\mathrm{d} 28$, respectively.

In general, the microstructure of all samples was similar in that the yogurt protein matrices were composed of casein micelle chains and clusters. The ways in which the casein micelles were linked to each other differed slightly. The resulting matrices appeared to be relatively more compact (denser) in the fortified yogurt than in the nonfortified yogurt at d 1 (Figure 6, panels c and a, respectively), which could be due to the fortified product containing more protein (Table 1). The more open matrices were due to larger pore spaces, and were evident in the microstructure of both yogurts at the end of the storage period.

The compactness of casein micelle matrix in liquid or yogurt has been studied by some researchers. Mimouni et al. (2010) reported that the microstructure of rehydrated milk protein concentrate powder particles in water was influenced by the storage period of the powder, and they observed increased interactions occurring between and within casein micelles. This led to compaction of the casein micelles and formation of 


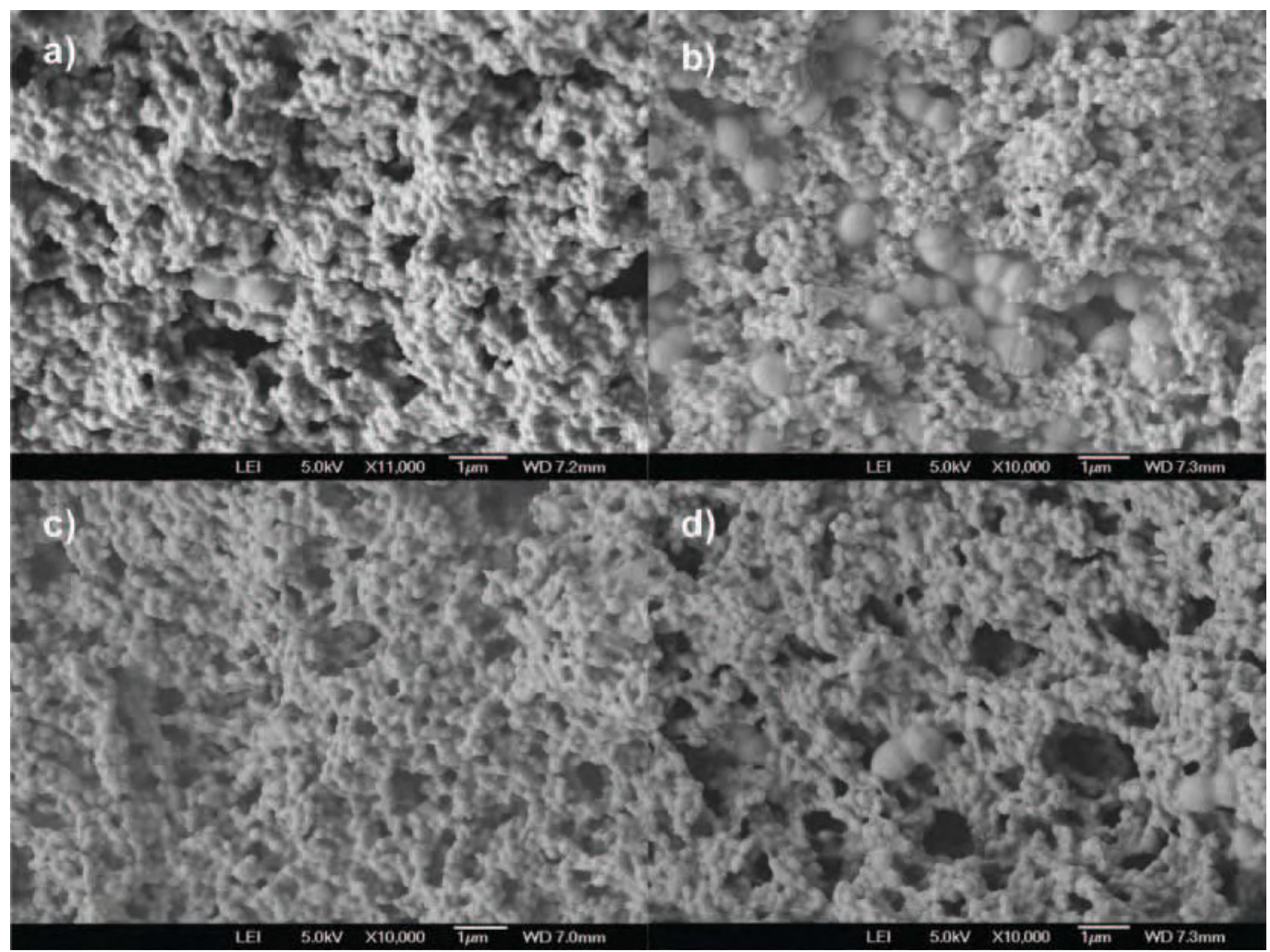

Figure 6. Scanning electron micrographs showing the structure of nonfortified (panels a and b at d 1 and 28 , respectively) and fortified (panels c and d at d 1 and 28 , respectively) yogurts during cold storage.

a monolayer skin of casein micelles, which were closely packed. Sodini et al. (2005a) studied the microstructure of yogurt and observed changes in the formation of the gel due to denaturation of proteins when the samples were enriched with milk proteins. Tamime et al. (1984) reported that the use of $\mathrm{Na}-\mathrm{CN}$ to fortify the milk base of set-type yogurt resulted in the most open casein matrix, consisting of robust casein particle chains and larger clusters. Transmission electron microscopy of the same yogurt showed some fusion of the casein particles that were relatively "smooth" without any spikes or appendages. According to Lee and Lucey (2003), the presence of high numbers of pores indicates a weaker gel, suggesting that weak interactions were present between the casein particles. Thus, it could be suggested that modifications within the protein micelles occurred during storage of the products for $28 \mathrm{~d}$, which resulted in weaker structures after storage at $<10^{\circ} \mathrm{C}$ in the current study.

\section{CONCLUSIONS}

Partial replacement of SMP (45\%) with WPC and $\mathrm{Na}-\mathrm{CN}$ to increase the protein content by $1 \mathrm{~g}$ protein/100 $\mathrm{g}$ in the milk base enhanced the rheological and sensory properties of probiotic stirred-type yogurt during cold storage. Although the acidification profile was not affected by supplementation with WPC and $\mathrm{Na}-\mathrm{CN}$, the viable counts of the probiotic bacteria were high and achieved the recommended level of health benefit for daily intake by humans. The fortified yogurt had a more compact microstructure and had smaller pores compared with the nonfortified yogurt.

\section{ACKNOWLEDGMENTS}

The authors thank DSM Food Specialties and Global Foods for the donation of cultures and ingredients, respectively, and FAPESP (São Paulo, Brazil; Process. 2007/03588-8) and CNPq (Brasília, Brazil) for financial support.

\section{REFERENCES}

Akalin, A. S., G. Unal, S. Gonc, and S. Fenderya. 2008. Effects of whey protein concentrate and fructooligosaccharide on the rheological and sensory properties of reduced-fat probiotic yoghurt. Milchwissenschaft 63:171-174.

Almeida, K. E., A. Y. Tamime, and M. N. Oliveira. 2009. Influence of total solids contents of milk whey on the acidifying profile and viability of various lactic acid bacteria. Lebenson. Wiss. Technol. 42:672-678. 
AOAC. 1995. Official Methods of Analysis. 16th ed. AOAC International, Arlington, VA.

Béal, C., and G. Corrieu. 1994. Viability and acidification activity of pure and mixed starters of Streptococcus salivarius ssp. thermophilus 404 and Lactobacillus delbrueckii ssp. bulgaricus 398 at the different steps of their production. Lebenson. Wiss. Technol. 27:86-92.

Bhullar, Y. S., M. A. Uddin, and N. P. Shah. 2002. Effects of ingredients supplementation on textural characteristics and microstructure of yoghurt. Milchwissenschaft 57:328-332.

Cruz, A. G., R. S. Cadena, E. H. M. Walter, D. Granato, J. A. F. Faria, and H. M. A. Bolini. 2010. Sensory analysis: Relevance for prebiotic, probiotic and synbiotic food development. Comp. Rev. Food Sci. Food Safety 9:358-373.

Damin, M. R., M. R. Alcantara, A. P. Nunes, and M. N. Oliveira. 2009. Effects of milk supplementation with skim milk powder, whey protein concentrate and sodium caseinate on acidification kinetics, rheological properties and structure of nonfat stirred yogurt. Lebenson. Wiss. Technol. 42:1744-1750.

Damin, M. R., E. Minowa, M. R. Alcantara, and M. N. Oliveira. 2008. Effect of cold storage on culture viability and some rheological properties of fermented milk prepared with yogurt and probiotic bacteria. J. Texture Stud. 39:40-55.

Dannemberg, F., and H. G. Kessler. 1988. Effect of denaturation of $\beta$-lactoglobulin on texture properties of set-style nonfat yoghurt. 1. Firmness and flow properties syneresis. Milchwissenschaft 43:700-730.

Dave, R. I., and N. P. Shah. 1997. Viability of yoghurt and probiotic bacteria in yoghurts made from commercial starter cultures. Int. Dairy J. 7:31-41

Dethemers, A. E. 1981. Sensory evaluation guide for testing food and beverage products. Food Technol. 11:50-57.

Florence, A. C. R., R. C. da Silva, A. P. D. Santo, L. A. Gioielli, A. Y. Tamime, and M. N. de Oliveira. 2009. Increased CLA content in organic milk fermented by bifidobacteria or yoghurt cultures. Dairy Sci. Technol. 89:541-553.

Granato, D., I. A. Castro, and F. Katayama. 2010. Assessing the association between phenolic compounds and the antioxidant activity of Brazilian red wines using chemometrics. Lebenson. Wiss. Technol. 43:1542-1549.

Grappin, R., and E. Beuvier. 1997. Possible implications of milk pasteurization on the manufacture and sensory quality of ripened cheese: A review. IDF Bull. Vol. 327. International Dairy Federation, Brussels, Belgium.

Isleten, M., and Y. Karagul-Yuceer. 2006. Effects of dried dairy ingredients on physical and sensory properties of nonfat yogurt. J. Dairy Sci. 89:2865-2872.

Lee, W. J., and J. A. Lucey. 2003. Rheological properties, whey separation, and microstructure in set-style yogurt: Effects of heating temperature and incubation temperature. J. Texture Stud. 34:515-536.

Lucas, A., I. Sodini, C. Monnet, P. Jolivet, and G. Corrieu. 2004. Effect of milk base and starter culture on acidification, texture, and probiotic cell counts in fermented milk processing. J. Dairy Sci. $85: 2479-2488$

Lucey, J. A. 2001. The relationship between rheological parameters and whey separation in milk gels. Food Hydrocoll. 15:603-608.

Lucey, J. A., M. Tamehana, H. Singh, and P. A. Munro. 1998. A comparison of the formation, rheological properties and microstructure of acid skim milk gels made with bacterial cultures or glucono- $\delta$ lactone. Food Res. Int. 31:147-155.

Marafon, A. P., A. Sumi, M. R. Alcantara, A. Y. Tamime, and M. N. Oliveira. 2011. Optimization of the rheological properties of probiotic yoghurts supplemented with milk proteins. Lebenson. Wiss. Technol. 44:511-519

Martinéz, C. G., M. Becerra, M. Cháfer, A. Albor, J. M. Carot, and A. Chiralt. 2003. Influence of substituting milk powder for whey powder on yogurt quality. Food Sci. Technol. 13:334-340.
Mimouni, A., H. C. Deeth, A. K. Whittaker, M. J. Gidley, and B. R. Bhandari. 2010. Investigation of the microstructure of milk protein concentrate powders during rehydration: Alterations during storage. J. Dairy Sci. 93:463-472.

Moraes, M. A. C. 1985. Métodos para Avaliação Sensorial dos Alimentos. UNICAMP, Campinas, Brazil.

Muños, A. M., G. V. Civille, and B. T. Carr. 1992. Sensory Evaluation in Quality Control. Van Nostrand Reinhold, New York, NY.

Oliveira, M. N., I. Sodini, F. Remeuf, and G. Corrieu. 2001. Effect of milk supplementation and culture composition on acidification, textural properties and microbiological stability of fermented milks containing probiotic bacteria. Int. Dairy J. 11:935-942.

Picque, D., B. Perret, E. Latrille, and G. Corrieu. 1992. Characterization and classification of lactic acid bacteria based on the acidification kinetics. Lebenson. Wiss. Technol. 25:181-186.

Rault, A., M. Bouix, and C. Béal. 2009. Fermentation pH influences the physiological-state dynamics of Lactobacillus bulgaricus CFL1 during pH-controlled culture. Appl. Environ. Microbiol. 75:43744381

Remeuf, F., S. Mohammed, I. Sodini, and J. P. Tissier. 2003. Preliminary observations on the effects of milk fortification and heating on microstructure and physical properties of stirred yogurt. Int Dairy J. 13:773-782.

Saccaro, D. M., A. Y. Tamime, A. L. O. S. Pilleggi, and M. N. Oliveira. 2009. The viability of three probiotic organisms grown with yoghurt starter cultures during storage for 21 days at 4 degrees $\mathrm{C}$. Int. J. Dairy Technol. 62:397-404.

Séverin, S., and X. Wenshui. 2005. Milk biologically active components as nutraceuticals: Review. Crit. Rev. Food Sci. Nutr. 45:645-656.

Shah, N. P. 2001. Functional foods from probiotics and prebiotics. Food Technol. 55:46-53.

Sodini, I., A. Lucas, J. Tissier, and G. Corrieu. 2005a. Physical properties and microstructure of yoghurts supplemented with milk protein hydrolysates. Int. Dairy J. 15:29-35.

Sodini, I., J. Montella, and P. S. Tong. 2005b. Physical properties of yogurt fortified with various commercial whey protein concentrates. J. Sci. Food Agric. 85:853-859.

Sodini, I., F. Remeuf, S. Haddad, and G. Corrieu. 2004. The relative effect of milk base, starter, and process on yogurt texture: A review. Crit. Rev. Food Sci. Nutr. 44:113-137.

Stone, H., and J. Sidel. 1993. Sensory Evaluation Practices. 2nd ed. Academic Press, San Diego, CA.

Tamime, A. Y. 2006. Probiotic Dairy Products. Blackwell Publishers, Ames, IA

Tamime, A. Y., A. Hasan, E. R. Farnworth, and T. Toba. 2007. Structure of fermented milks. Vol. Chapter 6 in Structure of Dairy Products. Wiley-Blackwell, Ames, IA

Tamime, A. Y., M. Kalab, and G. Davies. 1984. Microstructure of settype yoghurt manufactured from cow's milk fortified by various methods. Food Microstruct. 3:83-92.

Tamime, A. Y., and R. K. Robinson. 2007. Yoghurt: Science and Technology. 3rd ed. CRC, Boca Raton, FL.

Vasiljevic, T., and N. P. Shah. 2008. Probiotics-From Metchnikoff to bioactives. Int. Dairy J. 18:714-728.

Venturoso, R. C., K. E. Almeida, A. M. Rodrigues, M. R. Damin, and M. N. Oliveira. 2007. Determination of the physical-chemical composition of dairy products: Exploratory study to compare the results obtained by classic methodology and by ultra-sound. Braz. J. Pharmaceut. Sci. 43:607-613.

Wang, Y., G. Corrieu, and C. Béal. 2005. Fermentation pH and temperature influence the cryotolerance of Lactobacillus acidophilus RD758. J. Dairy Sci. 88:21-29.

Xu, Z. M., D. G. Emmanouelidou, S. N. Raphaelides, and K. D. Antoniou. 2008. Effects of heating temperature and fat content on the structure development of set yogurt. J. Food Eng. 85:590-597. 